\title{
Changing trends in mastitis
}

Zadoks RN, Fitzpatrick JL

Moredun Research Institute, Pentlands Science Park, Bush Loan, Penicuik, EH26 OPZ

Scotland, UK

\begin{abstract}
The global dairy industry, the predominant pathogens causing mastitis, our understanding of mastitis pathogens and the host response to intramammary infection are changing rapidly. This paper aims to discuss changes in each of these aspects. Globalisation, energy demands, human population growth and climate change all affect the dairy industry. In many western countries, control programs for contagious mastitis have been in place for decades, resulting in a decrease in occurrence of Streptococcus agalactiae and Staphylococcus aureus mastitis and an increase in the relative impact of Streptococcus uberis and Escherichia coli mastitis. In some countries, Klebsiella spp. or Streptococcus dysgalactiae are appearing as important causes of mastitis. Differences between countries in legislation, veterinary and laboratory services and farmers' management practices affect the distribution and impact of mastitis pathogens. For pathogens that have traditionally been categorised as contagious, strain adaptation to human and bovine hosts has been recognised. For pathogens that are often categorised as environmental, strains causing transient and chronic infections are distinguished. The genetic basis underlying host adaptation and mechanisms of infection is being unravelled. Genomic information on pathogens and their hosts and improved knowledge of the host's innate and acquired immune responses to intramammary infections provide opportunities to expand our understanding of bovine mastitis. These developments will undoubtedly contribute to novel approaches to mastitis diagnostics and control.
\end{abstract}

KEYWORDS: bovine; genetics; host; mastitis; molecular typing; pathogen

\section{CORRESPONDING AUTHOR:}

Ruth N Zadoks

Moredun Research Institute, Pentlands Science Park, Bush Loan, Penicuik, EH26 OPZ

Scotland, UK

Tel: +44 (0)131 4455111

Fax: $+44(0) 1314456111$

E-mail: ruth.zadoks@moredun.ac.uk

Irish Veterinary Journal volume 62 Supplement 59-70 2009

\section{TRENDS IN THE INDUSTRY}

The dairy industry worldwide has achieved many significant advances over the last fifty years, with knowledge-based genetic selection and optimised nutrition playing important roles in the delivery of increased milk yields of improved quality in most breeds (Shook 2006). Increasingly, the health and welfare of dairy cattle is seen as vital to maximise profitability and to enhance public perception of modern dairy systems (Kelton 2006; Mulligan et al. 2006). The next few decades are likely to present complex challenges for dairy farmers. Many of these challenges will result from national or international policies and from commercial decisions made by leaders in different countries around the world.

The world population is anticipated to reach nine billion people by 2050 . The highest rate of growth is likely to be in developing countries in Africa and Asia, while the population of continents such as Europe should remain relatively stable (UN 2004). More food than that which is currently being produced will be required to feed the world population in the future. The rate of growth in demand for agricultural products has declined from $2.2 \%$ per year over the last 30 years to an anticipated $1.5 \%$ per year until 2030 (FAO 2002). Growth is largely comprised of a higher demand for meat and milk products by increasingly wealthy countries such as India and China (Beghin 2006). The increased demand for products derived from livestock is not however restricted to richer countries, as in some of the poorest communities in the world, production of crops or vegetables are unsustainable, resulting in heavy reliance on milk and meat (Ahmed et al. 2002). In many of these countries there is an increasing awareness of the benefits to humans of consumption of even very small amounts of protein, especially by the young (Bhargava 2000) and the immunocompromised (Chevalier et al. 1998).

The world is now a global marketplace with many primary commodities and processed products travelling thousands of miles from production to consumption. The incentives for production are evolving with the decoupling of EU subsidies for meat production, the changes in handling of milk quota within the EU, and the ongoing negotiations on world trade under the General Agreements on Tariffs and Trade (www.wto.org). The UK was 59.3\% self-sufficient in food production in 2008, in comparison to $70.6 \%$ between 1995 and 1997 (DEFRA 2008). While this trend towards reduced self-sufficiency was seen as acceptable by some government departments, more recent debate has suggested that the UK public may be increasingly interested in issues of food security and supply. The last 
few years have seen a decline in the milk price in the UK. In the spring of 2007, prices began to increase and a price of 25.62 pence per litre was reported in February 2008. The reasons for this relatively sudden increase in price probably included flooding in the UK, concern about the reliability of supply from major retailers and an increase in global demand for liquid milk and dairy products (www. defra.gov.uk).

Current concerns about global warming and the adverse effect of greenhouse gases have influenced the perception of livestock farming, including the dairy industry. Approximately $10 \%$ of the total EU greenhouse gas emission has been attributed to agriculture (Lovett et al. 2006). Dairy cattle have also been associated with poor water quality arising from nitrate and phosphate excretion in some heavily-grazed areas. Opinions expressed on the competition between the use of grain as foodstuffs for humans or cattle, or for biofuels are intense and varied, and are at least in part driven by a $60 \%$ increase in cereal prices since 2005 (Müller et al. 2008). The significant demand for grain for whatever purpose adds pressure to an already severely pressurised dairy industry. This is likely to lead to further reductions in farm numbers with a resulting increase in the average herd size in surviving units. Climate change has been predicted to affect human morbidity and mortality significantly (Patz et al. 2005) and is likely to reduce the area of landmass available for agricultural purposes due to drought or flooding in many regions of the world. The Intergovernmental Panel on Climate Change (IPCC) has published detailed assessments of the effects, possible causes and options for mitigation of climate change (www.ipcc.ch). Yet another possible factor potentially adversely affecting production and trade of milk and milk products is the risk of agroterrorism aimed at the contamination or adulteration of food producing animals or their products (Wein and Liu 2005; Buttars et al. 2006).

In Europe and North America, current market demand and price for organic milk encourage dairy producers to consider organic production to improve the economic viability of their farm operations (Rotz et al. 2007). Milk from herds managed organically or conventionally, with or without use of recombinant bovine somatotropin (rbST), is similar in composition (Ellis et al. 2006, 2007; Vicini et al. 2008). There are, however, perceived nutritional and taste benefits among consumers of organic milk (Hill and Lynchehaun 2002). Environmental and health benefits are also cited as reasons for consumption of organic milk (Hill and Lynchehaun 2002), and consumers are willing to pay a high price for organic or rbST-free milk (American Farm Bureau 2008). On the other hand, environmental benefits as well as animal health benefits have been attributed to use of rBST in milk production (Allore and Erb 2000; Capper et al. 2008). Animal health did not appear to differ between organic and non-organic farms in the UK (Langford et al. 2009). Udder health was better in organic than conventional herds in Sweden (Hamilton et al. 2006), whereas poor udder health caused more culling in organic than conventional herds in Switzerland (Roesch et al. 2006). Comparison of disease rates between conventional and organic herds can be difficult because perception and detection of disease is influenced by management system (Ruegg 2008). Despite the media attention devoted to organic dairy products and large relative increases in demand for organic dairy products, consumption of organic products is mostly limited to affluent consumers, and organic consumption constitutes a small segment of total dairy consumption (Hill and Lynchehaun 2002).

The dilemma, which the dairy industry will have to face, is how to maximise production without compromising welfare, while reducing the impact of carbon emissions from dairy cattle. An important aspect of achieving these aims is to focus on overall lifetime productivity of cattle, rather than on traditional annual targets (VanRaden 2004). To achieve this aim, a reduction in morbidity and mortality due to preventable and prevalent endemic diseases is needed, one such disease being mastitis. If this is to become a reality, increased efforts are required in the speed and accuracy of detection of mastitis, better targeting of therapy, and improved management and decision making in prevention of exposure to pathogens and avoidance of significant risk factors for disease (LeBlanc et al. 2006). If successful, a holistic approach to preventing and controlling mastitis may benefit communities across the world, in both nutritional and environmental terms.

\section{TRENDS AT PATHOGEN LEVEL}

In most countries, the major mastitis pathogens are Streptococcus agalactiae, Streptococcus dysgalactiae and Streptococcus uberis, Staphylococcus aureus, and Escherichia coli. The word "major" reflects their considerable impact on cow health, milk quality and productivity. When the standard mastitis prevention programme was developed in England (Neave et al. 1969), Gram-positive pathogens such as Streptococcus and Staphylococcus species were the predominant causative agents of mastitis. Many infections caused by these pathogens were subclinical and chronic. The standard mastitis prevention programme aimed to reduce the prevalence of such infections by limiting the number of new infections and the duration of infections, recognizing that incidence and duration are the driving forces behind prevalence (Dodd et al. 1969). Implementation of these measures lead to a reduction in prevalence of Strep. agalactiae, Strep. dysgalactiae, Staph. aureus, and, to a lesser extent, Strep. uberis in individual herds (Neave et al. 1969). As more herds implement the standard control measures, pathogen populations at regional or national level start to shift. In some European countries, e.g. Belgium, Denmark, Norway and the UK, occurrence of Strep. agalactiae is now sporadic (Andersen et al. 2003; Østerås et al. 2006; Bradley et al. 2007; Piepers et al. 2007). In other areas, Strep. agalactiae is still quite 
common, e.g. in parts of Europe [Germany: $29 \%$ of herds positive (Tenhagen et al. 2006)] and the Americas [Brazil: $60 \%$ of herds positive (Duarte et al. 2004); Uruguay: $11 \%$ of herds positive (Gianneechini et al. 2002); New York, USA: $10 \%$ of cows positive (Wilson et al. 1997)]. Subclinical mastitis constitutes a major source of economic loss for dairy farms due to unrealised production potential and decreased milk quality (Hortet and Seegers, 1998; Huijps et al. 2008). The feasibility (Neave et al. 1969) and economic benefit (Yamagata et al. 1987; Edmondson 1989; Erskine and Eberhart 1990) of Strep. agalactiae control have been demonstrated repeatedly. This should provide every producer with the incentive to control Strep. agalactiae mastitis, and to use resources for milk production in a more efficient manner. In reality, motivation of producers to control mastitis may depend on bonus and penalty systems (Dekkers et al. 1996; Allore and Erb 1998; Nightingale et al. 2008). Regulatory limits for bulk milk somatic cell counts (BMSCC), which reflect mastitis prevalence in a herd (Eberhart et al. 1982), differ between countries or are entirely lacking. In Colombia, for example, the dairy industry cannot keep up with current demand. The need for milk quantity outweighs the need for milk quality, and there is currently no legislation or laboratory capacity to regulate and measure BMSCC in Colombia. Producers' ability to control mastitis will depend on access to knowledge, diagnostic facilities, and animal health products. An increasing number of cows are milked in Latin America or by Hispanic milkers in the USA. To provide Spanish-speakers with access to information on mastitis control, a growing number of organisations provide bi-lingual milker training and translation of educational materials (NMC 2008; Quality Milk Production Services 2008; University of Wisconsin 2008).

In parallel with the decreases in national average BMSCC and prevalence of Strep. agalactiae, a decrease in prevalence of Staph. aureus has been seen in some countries. In Finland, BMSCC decreased from 320,000 cells/ml in 1990 to 180,000 cells/ml in 1995 and Staph. aureus prevalence decreased from 31\% to $17 \%$ of isolations (Myllys et al. 1998). As BMSCC and prevalence of major pathogens decrease, the relative importance of other organisms, particularly coagulase negative staphylococci (CNS), increases. In the Netherlands, the prevalence of CNS among bacterial isolates from milk samples increased from $16.2 \%$ in 1999 to $42.2 \%$ in 2004 for subclinical mastitis, and from $7.3 \%$ to $14.1 \%$ for clinica mastitis (Sampimon et al. 2007). CNS are now among the most commonly isolated organisms from milk samples of cows with subclinical mastitis in many countries (RajalaSchultz et al. 2004; Østerås et al. 2006; Tenhagen et al. 2006; Bradley et al. 2007). In 2007, the first international symposium on CNS in bovine mastitis was organised, reflecting the increasing recognition of the potential importance of this group of pathogens (De Vliegher et al. 2009). Molecular methods for identification of CNS provide accurate tools for epidemiological studies at CNS species level and future development of species-specific recommendations for treatment and prevention of CNS mastitis (Zadoks and Watts 2009).

Despite improvements in control of subclinical mastitis, control of clinical mastitis continues to constitute a major challenge (Hillerton et al. 1995). The main organisms associated with clinical mastitis in England and Wales are E. coli and Strep. uberis (Milne et al. 2002; Peeler et al. 2003; Bradley et al. 2007). A steady increase in relative importance of Strep. uberis can be seen over the decades, with $15,17,21$ and $24.5 \%$ of clinical mastitis cases attributed to this species in 1969, 1980, 1993 and 2005, respectively (Neave et al. 1969; Bramley 1984; Hillerton et al. 1993; Bradley et al. 2007). When accounting for the incidence of clinical mastitis per 100 cows per year, however, the absolute incidence of Strep. uberis mastitis decreased from 21 cases per 100 cows in 1969 (Neave et al. 1969), to only seven or eight cases per 100 cows in 1980 (Bramley 1984) and 1993 (Hillerton et al. 1993). In recent years, reported Strep. uberis incidence has increased again, with 16 cases/100 cows/year reported for 2005 (Bradley et al. 2007). The second most common group of pathogens causing clinical mastitis in England and Wales consists of E. coli and other Enterobacteriaceae (Milne et al. 2002; Bradley et al. 2007). In New Zealand, as in the UK, Strep. uberis is the most common pathogen associated with clinical mastitis, but in contrast to the situation in the UK, E. coli mastitis is rarely observed (McDougall 2003). In Norway, neither Strep. uberis nor E. coli are commonly found. Rather, Staph. aureus and Strep. dysgalactiae are the most common causes of clinical mastitis (Whist et al. 2007). Staphylococcus aureus is the main pathogen associated with clinical mastitis in The Netherlands, followed by E. coli and Strep. dysgalactiae (Barkema et al. 1998). Mycoplasma (González and Wilson 2003; Fox et al. 2005) and Klebsiella (Hoe and Ruegg 2005; Munoz et al. 2007; Paulin-Curlee et al. 2007) mastitis are major concerns in the USA. Faecal shedding of Klebsiella is thought to contribute to exposure and mastitis incidence in dairy herds in the USA (Munoz et al. 2006; 2007). By contrast, Klebsiella mastitis outbreaks are only occasionally reported from Europe and they are predominantly associated with contaminated sawdust bedding (Vecht et al. 1987; Sampimon et al. 2006). Mycoplasma mastitis is only occasionally reported from Europe (Blackburn et al. 2007; Tolboom et al. 2008). Increasingly, milk samples from clinical mastitis cases are culture-negative. Culture-negative samples were obtained from approximately 25 to $30 \%$ of clinical cases in studies in the UK (Milne et al. 2002; Bradley et al. 2007) and the USA (Hoe and Ruegg 2005). It has been proposed that culture negative cases should be attributed to coliform organisms, and that our diagnostic methods and criteria, which were developed for detection of chronic, subclinical infections, need to be updated to be appropriate for the changed spectrum of mastitis pathogens (Bradley et al. 2005). Use of PCR based methods may also contribute 
to improved mastitis diagnostics, e.g., through increased sensitivity of detection of Staph. aureus (Graber et al. 2007) or organisms that are non-viable or difficult to culture (Barlow et al. 2008).

Considering that different pathogens are the predominant cause of clinical mastitis in different countries, mastitis controls will need to be developed to meet the specific requirements of an individual country or segment of the dairy industry. Some mastitis control strategies, e.g., vaccination against coliform mastitis, are widely adopted in one country (USA) but may not be available in other countries (e.g, The Netherlands) and not even relevant elsewhere (New Zealand, Norway). Targeted intervention strategies are being developed and implemented in a number of countries (Green et al. 2007; Lam et al. 2007; www.countdown.org.au). Significant improvements in udder health have been reported (Green et al. 2007), but adoption and success rates depend on farmer motivation and behaviour (Lam et al. 2007). Insight into socioeconomic factors that motivate farmers to control mastitis may be as important as scientific or technical knowledge to improve uptake of mastitis control measures (Lam et al. 2007).

\section{TRENDS AT STRAIN LEVEL}

The application of molecular or DNA-based methods in mastitis research and diagnostics has contributed to an increased understanding of mastitis epidemiology and control options. Using these methods, isolates belonging to a bacterial species can be differentiated at the subspecies or strain level, allowing for improved recognition of sources and transmission routes of pathogens (Zadoks and Schukken 2006).

Streptococcus agalactiae is the quintessential contagious mastitis pathogen. It mostly causes subclinical infections and implementation of the standard mastitis prevention programme has all but eradicated this organism from several countries in Western Europe. Occasionally, clinical Strep. agalactiae mastitis is observed in herds with good control of contagious mastitis, as evidenced by low BMSCC (<150,000 cells/ml) (Barkema et al. 1998). Clinical episodes of Strep. agalactiae mastitis can also be induced experimentally (Jensen 1982). They are generally shortlived and do not result in transmission of the pathogen in the herd. Occurrence of Strep. agalactiae in bulk tank milk from herds without evidence for transmission or presence of the pathogen in individual cow has been attributed to cross contamination between loads of milk (Andersen et al. 2003). Other authors attribute the occurrence of incidental clinical mastitis and the presence of Strep. agalactiae in bulk tank milk obtained from Strep. agalactiaefree animals to introduction of human Strep. agalactiae strains (Zadoks and Schukken 2006). Strep. agalactiae or Group B Streptococcus (GBS) is highly prevalent in humans, with carriage rates of $30 \%$ or more in the urogenital and distal gastrointestinal tracts of women (Manning et al. 2000; Meyn et al. 2002; Hansen et al. 2004) and close to $25 \%$ in men (Manning et al. 2000). Maternal carriage of Strep. agalactiae may result in neonatal infection, with subsequent sepsis, meningitis, permanent neurological damage, or death of newborns. Human and bovine isolates largely constitute genetically distinct subpopulations within the bacterial species (Bisharat et al. 2004; Bohnsack et al. 2004; Dogan et al. 2005; Sukhnanand et al. 2005). Canine and feline strains of Strep. agalactiae are genetically similar to human rather than bovine strains (Yildirim et al. 2002). A virulent human strain of Strep. agalactiae that is significantly associated with invasive neonatal disease has evolved from bovine strains of Strep. agalactiae (Bisharat et al. 2004). To prevent emergence of additional human-pathogenic strains from a bovine Strep. agalactiae reservoir, it has been suggested that the pathogen should be eradicated from the cattle population (Hillerton et al. 2004). Strep. agalactiae is highly prevalent in humans but relatively rare in UK dairy herds, and its presence in dairy herds may be the result or the cause of its presence in humans. Thus, it is uncertain whether elimination from cattle would be a cost-effective way to prevent human disease due to Strep. agalactiae.

Staphylococcus aureus has been more difficult to control using the standard mastitis prevention programme than Strep. agalactiae. This is due in part to difficulty in diagnosing and curing Staph. aureus infections (Barkema et al. 2006). In addition, Staph. aureus can be found in many sources, including bovine skin, non-bovine animals and humans, flies, and the barn environment. Strain typing studies show that some cases of Staph. aureus mastitis are not due to contagious transmission but environmental in origin (Kapur et al. 1995; Rivas et al. 1997; Zadoks et al. 2000; Joo et al. 2001). The incidence of environmental Staph. aureus infections would not be affected by implementation of the standard mastitis prevention programme. Across countries and continents, more than $85 \%$ of bovine Staph. aureus mastitis is caused by a genetically closely related subpopulation of the species (Fitzgerald et al. 1997; Smith et al. 2005), which is adapted to the bovine host or, more specifically, to the bovine udder (Herron-Olson et al. 2007). Strains of Staph. aureus differ in their ability to spread from cow to cow (Smith et al. 1998; Zadoks et al. 2002) or to provoke an increase in somatic cell count (Zadoks et al. 2002), in impact on milk yield (Middleton and Fox 2002), and in response to antimicrobial treatment (Barkema et al. 2006). The full genome sequences of a number of Staph. aureus strains are now available (Baba et al. 2008). This allows for detailed examination of genetic elements or proteins that may be responsible for host or tissue adaptation (Herron-Olson et al. 2007). An improved understanding of such components may contribute to the development of new intervention strategies to control Staph. aureus mastitis (Fitzgerald et al. 2000; Mullarky et al. 2001). As for Strep. agalactiae, a virulent strain 
that poses a potential human health risk has arisen from a subpopulation of bovine Staph. aureus (Guinane et al. 2008). In addition, methicillin-resistant Staph. aureus in dairy cattle and cattle farmers is an increasing concern (Juhász-Kaszanyitzky et al. 2007; Moon et al. 2007; Van Loo et al. 2007). These findings lend new urgency to the need to improve control of Staph. aureus mastitis.

Whilst Staph. aureus is a contagious pathogen more than an environmental pathogen, the reverse is true for Strep. uberis (Zadoks 2007). Strain typing studies have revealed large genetic heterogeneity among Strep. uberis isolates obtained from animals within a single herd, particularly in New Zealand (Douglas et al. 2000; Wieliczko et al. 2002; McDougall et al. 2004; Pullinger et al. 2006), which proves absence of cow-to-cow transmission. In other studies, however, predominant strains of Strep. uberis have been observed within herds (Zadoks et al. 2003; Coffey et al. 2006), which might be explained by contagious transmission. In one outbreak, the milking machine was identified as a likely fomite for such transmission (Zadoks et al. 2003). Alternative explanations for strain predominance include overrepresentation of a strain in the environment, or host-adaptation of a subset of the Strep. uberis population (Zadoks and Schukken 2006). In studies from New Zealand, several common environmental strains were underrepresented among mastitis causing isolates (Lopez-Benavides et al. 2007; Pullinger et al. 2006), which argues against environmental strain predominance as a full explanation for strain predominance among bovine isolates. Modern genomic and proteomic methods enable us to explore the hostadaptation hypothesis (Zadoks 2007) as well as potential vaccine targets (Leigh et al. 2004). They may also help us understand why some Strep. uberis infections respond well to antimicrobial treatment, whereas others do not respond to prolonged intramammary therapy (Milne et al. 2005). In vitro, adherence of Strep. uberis and subsequent invasion and survival in mammary epithelial cells has been observed (Tamilselvam et al. 2006). Such processes could explain persistence of infection and treatment failures, but it is uncertain whether these observations are a reflection of events that take place in vivo (Leigh 1999). Use of infection models in animals will help to assess the relevance of these experiments and their potential contribution to our knowledge of disease causation and control.

Where Strep. agalactiae may be considered the quintessential contagious pathogen, $E$. coli can be considered the quintessential environmental pathogen and no evidence for cow-to-cow transmission of $E$. coli has been published yet. There is, however, emerging evidence for host-adaptation of E. coli. Most E. coli infections occur in early lactation in high producing cows, when immunosuppression through metabolic deficiencies (Suriyasathaporn et al. 2000a) or extremely low SCC (Suriyasathaporn et al. 2000b; Peeler et al. 2003) lowers the host's resistance. Infections tend to result in acute and often severe clinical mastitis with removal of the pathogen or removal of the cow as the two most likely outcomes. In other animals, however, recurrent episodes of clinical mastitis are observed, with considerable economic loss as a result (Bar et al. 2007). Recurrent clinical episodes may be due to cure and reinfection of a susceptible host. Alternatively, the bacteria and the cow may survive simultaneously, and subclinical episodes of a persistent infection may alternate with clinical episodes. Strain typing studies have confirmed the existence of both mechanisms (Döpfer et al. 1999, 2000; Bradley and Green 2001; Dogan et al. 2006). Persistence of $E$. coli infections is associated with invasion and survival of $E$. coli inside mammary epithelial cells in vitro (Dogan et al. 2006), a mechanism similar to that proposed for Strep. uberis. Virulence genes typically associated with invasion of diarrhoeagenic and uropathogenic pathogenic $E$. coli did not account for the invasive behaviour of mastitis-associated $E$. coli strains and the mechanism of invasion is as yet undetermined (Dogan et al. 2006). Whole genome comparison of $E$. coli strains associated with different disease syndromes may reveal genes that are specific to mastitis associated $E$. coli. Some cases of clinical E. coli mastitis that are observed in lactation are the result of infections that took place in the dry period (Bradley and Green 2000), implying that the dry period rather than peak lactation can be a critical time for control of $E$. coli mastitis. Use of internal teat sealants does not reduce the risk of dry-period infections with coliform bacteria significantly (Berry and Hillerton 2002; 2007)

Through use of genomic and proteomic tools, it will be possible to further explore how different subpopulations of pathogens differ in mechanisms of disease causation and transmission. A more developed understanding of the pathogenesis and epidemiology of bovine mastitis will provide new approaches aimed at improvements in mastitis control. Rapid, effective, and increasingly costeffective methods of sequencing pathogen genomes have already contributed new information to our understanding of host-pathogen interactions in mastitis. Manipulation of mastitis pathogens using molecular methods such as mutagenesis (Brouillette and Malouin 2005), and measurement of messenger RNA (transcriptomics), proteins or peptides (proteomics) and networks of metabolites (metabolomics), provide further opportunities to investigate mastitis pathogenesis at pathogen and host level (Lippolis and Reinhardt 2005; Smolenski et al. 2007; Taverna et al. 2007; Boehmer et al. 2008).

\section{TRENDS AT HOST LEVEL}

In many countries, the emphasis on improving dairy production has been to focus on breeds that have particularly high milk yields, especially Holstein, which is the most widespread dairy cattle breed, found in 128 countries worldwide (FAO 2007). In the USA, fewer than $5 \%$ of dairy cattle belong to breeds other than purebred 
or grade Holsteins (McAllister 2002). There has been a decrease in the numbers of more traditional breeds such as Jersey and Guernsey and Alpine breeds, which have lower milk yields but better quality milk than the Holstein breed in terms of benefits to human health or processing qualities (Ellis et al. 2006; De Marchi et al. 2007; Kamiski et al. 2007). Selection of dairy cattle over the years has been based on phenotypic traits such as teat length, udder placement and 'dairy type', however, increased emphasis on selection of sires for traits such as predicated transmitting ability for somatic cell counts, an indirect measurement of mastitis susceptibility, and for economic traits such as profit index, total economic index and profitable life index, are becoming commonplace (Dekkers and Gibson 1998; Wicks and Leaver 2006). Selection of sires for these traits has increased the rate of change of phenotypic characteristics, for example milk yield and quality, however, this has occurred through selection of a relatively small number of very popular sires, especially within Holstein Friesians. In some animal species, selection of a small number of sires has been associated with genetic bottlenecks (Mikko and Andersson 1995; Rendo et al. 2004). This may result in reduced variation in the offspring, which may in turn have adverse effects on health and welfare. One gene complex which has been long recognised as being associated with mastitis susceptibility or resistance is the Major Histocompatibility Complex, where Class I (Vage et al. 1992) were found to be associated with health traits including measurements of somatic cell counts (Weigel et al. 1990) and Class II (Sharif et al. 2003) genes have been demonstrated as playing an important role in presenting antigen to cells of the immune system and in response of lymphocytes to mastitis pathogens (Park et al. 1993). More recently, other genes and gene complexes have been shown to play a role in the pathogenesis of mastitis, including Toll-like receptors (Opsal et al. 2008).

In some countries, priorities such as the adaptability of cows to once a day milking or for specific systems including low input or extensive management, have led to selection for characteristics other than milk yield. There is increasing interest in cross-breeding dairy cattle such as Norwegian Reds with one or more breeds (e.g. Holstein Friesian and/or Normande, Montbeliarde; Heins et al. 2006) in order to produce dairy cattle with reasonable production levels combined with a reduced susceptibility to some of the main production diseases including mastitis and endometritis (Heringstad et al. 2007). Changing breeding goals also reflect a growing public interest in sustainability of dairy cattle production, with consideration of market economic values and non-market values such as animal welfare (Oltenacu and Algers 2005; Nielsen et al. 2006). In contrast to the dominance of the Holstein breed in terms of cow numbers and contribution to dairy genetics, certain dairy breeds across the world have had their numbers reduced to such an extent, that their sustainability is threatened. One such example is the
Modicana breed of cattle, originating in Sicily where they produce very high quality hard cheese: Ragusano (Licitra et al. 1998). It is important that a genetic resource for minor breeds is maintained in order to protect against extinction and to ensure that beneficial genes could be re-introduced to the dairy cattle population should they be identified as required. The uncertainty of the direction of the dairy industry in terms of supply and demand, and in light of potential environmental impacts, makes maintenance of diversity in dairy cattle particularly important.

Requirements for liquid milk and dairy products in developing countries will require development of more efficient dairying systems and investment in the application of modern technologies where appropriate. Maintenance of dairy cattle in developing countries poses many challenges, especially breeding cattle, which are resistant to many of the diseases with high mortality such as theileriosis and trypanosomiasis (Freeman et al. 2004). In East Africa, dairy cattle are principally crossbreeds between European Bos taurus dairy breeds, including Ayrshire, Friesian or Jersey, and indigenous Bos indicus cattle such as Boran or Zebu (Msanga et al. 2000; Karimuribo et al. 2006). The Boran breed which is recognised for its relatively high milk yield compared to other cross-breeds, has been shown to be 3.4 times more likely to be affected by clinical and subclinical mastitis than the Tanzanian Shorthorn Zebu breed (Karimuribo et al. 2006). Selection of crossbred dairy cattle on the basis of greater milk yield may therefore need to be combined with an improvement in control programmemes for mastitis to ensure a sustainable industry.

Resistance to mastitis has been associated with both innate (Rainard and Riollet 2006) and acquired immunity (Kehrli and Harp 2001). Selection of cattle for breeding for mastitis resistance depends on measurement of humoral or cellular assays which are predicted as correlates of protection against intramammary infection (Dosogne et al. 2002; Shkreta et al. 2004). It is increasingly recognised that different mastitis species induce very different inflammatory and immune responses. Examples include the very rapid and relatively short-lived influx of neutrophils following infection with the Gram negative organisms such as E. coli (Mehrzad et al. 2004) and the more gradual concentration of lymphocytes, including regulatory $\mathrm{T}$ cells in mammary glands infected with Staph. aureus (Chang et al. 2005). Host genetics affect disease incidence and severity, and pathogen genetics may influence the host genetic structure. Therefore, the evolutionary impact of the interaction between the host and its pathogens needs to be taken into consideration to fully appreciate implications of breeding strategies aimed at mastitis prevention (Detilleux 2009).

Host responses to intramammary infection differ between pathogen species (Bannerman 2008; Bannerman et al. $2004 a, b)$ and pathogen strains. The ability of the host 
to prevent establishment of new intramammary infections is determined in part by the ability of neutrophils to phagocytose and kill pathogens. Pathogen strains that evade neutrophil killing are more likely to establish infection than those that do not. In vitro, Staph. aureus strains that produce enterotoxins are not killed as efficiently as enterotoxin negative strains (Mullarky et al. 2001). In a large collection of Staph. aureus isolates from three continents, enterotoxin producing strains were overrepresented among isolates that caused clinical mastitis (Mullarky et al. 2001), suggesting that the inability of the host immune system to deal efficiently with these strains results in increased likelihood of clinical disease. Whether it is the enterotoxins themselves that affect the immune response, or other virulence factors encoded by the agr-loci that enterotoxin production tends to be associated with, is not fully understood (Mullarky et al. 2001). For Strep. uberis, differences between strains in their ability to cause clinical mastitis have also been associated with differences in their ability to resist phagocytosis and killing by host neutrophils (Leigh et al. 1990). Analysis of large international collections of Strep. uberis has shown that isolates that carry the has $A$ gene, which encodes hyaluronate synthase and contributes to capsule formation, are more likely to cause clinical mastitis than other isolates (Coffey et al. 2006; Pullinger et al. 2006; Tomita et al. 2008). Initially, it was thought that capsule mediates resistance of Strep. uberis to phagocytosis and killing by bovine neutrophils (Leigh 1999), but later studies showed that the presence of capsule is not directly related to the bactericidal action of neutrophils (Field et al. 2003). Thus, the mechanisms underlying strain-specific host-immune responses to Staph. aureus and Strep. uberis remain to be elucidated. Mechanisms underlying strain specific interaction of pathogens with host mammary epithelial cells, as desribed for Strep. uberis (Matthews et al. 1994) and E. coli (Dogan et al. 2006) have not been identified either. Further studies are required to compare inter-strain variation in host response.

\section{SUMMARY AND OUTLOOK}

While this manuscript describes the trends considered by the authors as impacting significantly on the dairy and veterinary industries, many aspects discussed also potentially relate to infections of the mammae of humans and identification of the causes and effects of intramammary disease in lactating women. Breastfeeding mothers are at risk of clinical and possibly subclinical mastitis (Tomkins 2000; Foxman et al. 2002) and infectious mastitis is one of the main causes of premature weaning in lactating women (Delgado et al. 2008). The current focus on 'One Medicine' by the Centres for Disease Control and Prevention in the USA and the promotion of this approach by the editors of the British Medical Journal and The Veterinary Record (Alder and Easton 2005) aims to combine research efforts on human and veterinary diseases to provide benefits to all mammals in terms of effective response to terrorism, diseases and natural disasters. Some of the trends appearing in mastitis in dairy cattle raise issues of comparative medicine in addition to the impact of the disease on the availability and benefits of milk to the human population.

Recent scientific developments, specifically in the areas of genomics and proteomics at host and pathogen level, provide exponentially growing opportunities for a deepening of our understanding of mastitis pathogenesis and epidemiology. Whilst it is hoped that such scientific understanding will contribute to mastitis control, social, economic and climatic trends are likely to be the main drivers behind changes in milk production systems and mastitis control. At herd level, motivation of farmers is an essential driver. At the national level, regulatory and economic incentives may be used to drive farmer motivation. At a global level, food and fuel needs and changes in human population size, wealth distribution, climate and land availability and use will be major forces in determining the future of agriculture and dairy farming. Although there are many uncertainties surrounding estimates in anticipated population, climate and land use changes, one thing is clear: more people will need to be provided with animal-based food products using fewer natural resources. Thus, there is an urgent need to increase the efficiency of milk production. Mastitis control is a step towards reaching that goal.

\section{REFERENCES}

Ahmed M, Ehui S and Mohamed-Saleem MA (2002) Adoption of crossbred cow technologies and increase in food security among smallholder dairy farmers in the East African highlands. J Crop Prod (USA) 6(1/2), 319-337.

Alder M, Easton G (2005) Human and veterinary medicine. BMJ 330(7496), 858-859.

Allore HG, Erb HN (1998) Partial budget of the discounted annual benefit of mastitis control strategies. J Dairy Sci 81(8) 2280-2292.

Allore HG, Erb HN (2000) Simulated effects on dairy cattle health of extending the voluntary waiting period with recombinant bovine somatotropin. Prev Vet Med 46(1), 29-50.

American Farm Bureau (2008) Retail food prices up at beginning of 2008 [Online] Available from: www.fb.org/index.php?fuseaction=newsroom. newsfocus\&year $=2008 \&$ file $=$ nr0327.html $[$ Accessed 5 December 2008].

Andersen HJ, Pedersen LH, Aarestrup FM et al. (2003) Evaluation of the surveillance programme of Streptococcus agalactiae in Danish dairy herds. J Dairy Sci 86(4), 1233-1239.

Baba T, Bae T, Schneewind O et al. (2008) Genome sequence of Staphylococcus aureus strain Newman and comparative analysis of staphylococcal genomes: polymorphism and evolution of two major pathogenicity islands. J Bacteriol 190(1), 300-310.

Bannerman DD, Paape MJ, Goff JP et al. (2004a) Innate 
immune response to intramammary infection with Serratia marcescens and Streptococcus uberis. Vet Res 35(6), 681700.

Bannerman DD, Paape MJ, Lee JW et al. (2004b) Escherichia coli and Staphylococcus aureus elicit differential innate immune responses following intramammary infection. Clin Diagn Lab Immunol 11(3), 463-472.

Bannerman DD (2008) Pathogen-dependent induction of cytokines and other soluble inflammatory mediators during intramammary infection of dairy cows. Aug 15.

Bar D, Gröhn YT, Bennett G et al. (2007) Effect of repeated episodes of generic clinical mastitis on milk yield in dairy cows. J Dairy Sci 90(10), 4643-4653.

Barkema HW, Schukken YH, Lam TJ et al. (1998) Incidence of clinical mastitis in dairy herds grouped in three categories by bulk milk somatic cell counts. J Dairy Sci 81(2), 411-419.

Barkema HW, Schukken YH and Zadoks RN (2006) Invited Review: The role of cow, pathogen, and treatment regimen in the therapeutic success of bovine Staphylococcus aureus mastitis. J Dairy Sci 89(6), 1877-1895.

Barlow J, Rauch B, Welcome F et al. (2008) Association between Coxiella burnetii shedding in milk and subclinical mastitis in dairy cattle. Vet Res 39(3), 23, doi: 10.1051/vetres:2007060.

Beghin JC (2006) Evolving dairy markets in Asia: recent findings and implications. Food Policy 31(3), 195-200.

Berry EA, Hillerton JE (2002) The effect of an intramammary teat seal on new intramammary infections. JDairy Sci 85(10), 2512-2520.

Berry EA, Hillerton JE (2007) Effect of an intramammary teat seal and dry cow antibiotic in relation to dry period length on postpartum mastitis. J Dairy Sci 90(2), 760765.

Bhargava A (2000) Modeling of the effects of maternal nutritional status and socioeconomic variables on the anthropometric and psychological indicators of Kenyan infants from age 0-6 months. Am J Phys Anthropol 111(1), 89-104.

Bisharat N, Crook DW, Leigh J et al. (2004) Hyperinvasive neonatal group $B$ streptococcus has arisen from a bovine ancestor. J Clin Microbiol 42(5), 2161-2167.

Blackburn P, Brooks C, McConnell W et al. (2007) Isolation of Mycoplasma bovis from cattle in Northern Ireland from 1999 to 2005. Vet Rec 161(13), 452-453.

Boehmer JL, Bannerman DD, Shefcheck K et al. (2008) Proteomic analysis of differentially expressed proteins in bovine milk during experimentally induced Escherichia coli mastitis. J Dairy Sci 91(11), 4206-4218.

Bohnsack JF, Whiting AA, Martinez G et al. (2004) Serotype III Streptococcus agalactiae from bovine milk and human neonatal infections. Emerg Infect Dis 10(8), 1412-1419.

Bradley AJ, Green MJ (2000) A study of the incidence and significance of intramammary enterobacterial infections acquired during the dry period. J Dairy Sci 83(9), 19571965.

Bradley AJ, Green MJ (2001) Adaptation of Escherichia coli to the bovine mammary gland. J Clin Microbiol 39(5), 1845-1849.
Bradley AJ, Leach KA, Breen JE et al. (2007) Survey of the incidence and aetiology of mastitis on dairy farms in England and Wales. Vet Rec 160(8), 253-257.

Bradley AJ, Newton H and Green MJ (2005) Use and interpretation of bacteriology in the diagnosis of bovine intramammary infection. In: Proceedings of the 4th IDF International Mastitis Conference, Maastricht, The Netherlands. Pp 409-415.

Bramley AJ (1984) Streptococcus uberis udder infection - a major barrier to reducing mastitis incidence. Br Vet J 140(4), 328-335.

Brouillette E, Malouin F (2005) The pathogenesis and control of Staphylococcus aureus-induced mastitis: study models in the mouse. Microbes Infect 7(3), 560-568.

Buttars NK, Young AJ and Bailey D (2006) Adoption of security systems by dairy farms to address bioterrorist threats in the intermountain United States. J Dairy Sci 89(5), 1822-1829.

Capper JL, Castañeda-Gutiérrez E, Cady RA et al. (2008) The environmental impact of recombinant bovine somatotropin (rbST) use in dairy production. Proc Natl Acad Sci U S A 105(28), 9668-9673.

Chang BS, Bohach GA, Lee SU et al. (2005) Immunosuppression by $\mathrm{T}$ regulatory cells in cows infected with staphylococcal superantigen. J Vet Sci 6(3), 247-250.

Chevalier P, Sevilla R, Sejas E et al. (1998) Immune recovery of malnourished children takes longer than nutritional recovery: implications for treatment and discharge. J Trop Pediatr 44(5), 304-307.

Coffey TJ, Pullinger GD, Urwin R et al. (2006) First insights into the evolution of Streptococcus uberis: a multilocus sequence typing scheme that enables investigation of its population biology. Appl Environ Microbiol 72(2), 1420-1428.

DEFRA (2008) The Environmental Impact of Livestock Production. Review of Research and Literature [Online]. Available from: www.defra.gov.uk/farm/livestock/pdf/ envimpacts-livestock.pdf [Accessed December 7 2008].

Dekkers JC, Gibson JP (1998) Applying breeding objectives to dairy cattle improvement. J Dairy Sci 81(S2), 19-35.

Dekkers JC, Van Erp T and Schukken YH (1996) Economic benefits of reducing somatic cell count under the milk quality programme of Ontario. J Dairy Sci 79(3), 396401.

Delgado S, Arroyo R, Martín R et al. (2008) PCR-DGGE assessment of the bacterial diversity of breast milk in women with lactational infectious mastitis. BMC Infect Dis 8, 51, doi:10.1186/1471-2334-8-51.

De Marchi M, Dal Zotto R, Cassandro M et al. (2007). Milk coagulation ability of five dairy cattle breeds. J Dairy Sci 90(8), 3986-3992.

De Vliegher S, Zadoks RN and Barkema HW (2009) Heifer and CNS mastitis. Vet Microbiol 134(1-2), 1-2

Detilleux JC (2009) Genetic factors affecting susceptibility to udder pathogens. Vet Microbiol.Vet Microbiol 134(1-2), 157-164

Dodd FH, Westgarth DR, Neave FK et al. (1969) Mastitis: the strategy of control. J Dairy Sci 52(5), 689-695.

Dogan B, Klaessig S, Rishniw M et al. (2006) Adherent and invasive Escherichia coli are associated with persistent bovine mastitis. Vet Microbiol 116(54), 270-282. 
Dogan B, Schukken YH, Santisteban C et al. (2005) Distribution of serotypes and antimicrobial resistance genes among Streptococcus agalactiae isolates from bovine and human hosts. J Clin Microbiol 43(12), 58995906.

Döpfer D, Almeida RA, Lam TJ et al. (2000) Adhesion and invasion of Escherichia coli from single and recurrent clinical cases of bovine mastitis in vitro. Vet Microbiol 74(4), 331-343.

Döpfer D, Barkema HW, Lam TJ et al. (1999) Recurrent clinical mastitis caused by Escherichia coli in dairy cows. J Dairy Sci 82(1), 80-85.

Dosogne H, Vangroeneweghe F and Burvenich C (2002) Potential mechanism of action of J5 vaccine in protection against sever bovine coliform mastitis. Vet Res 33(1),1-12.

Douglas VL, Fenwick SG, Pfeiffer DU et al. (2000) Genomic typing of Streptococcus uberis isolates from cases of mastitis, in New Zealand dairy cows, using pulsed-field gel electrophoresis. Vet Microbiol 75(1), 27-41.

Duarte RS, Miranda OP, Bellei BC et al. (2004) Phenotypic and molecular characteristics of Streptococcus agalactiae isolates recovered from milk of dairy cows in Brazil. J Clin Microbiol 42(9), 4214-4222.

Eberhart RJ, Hutchinson $\sqcup$ J and Spencer SB (1982) Relationships of bulk tank somatic cell counts to prevalence of intramammary infection to indices of herd production. J Food Prot 45(12), 1125-1128.

Edmondson PW (1989) An economic justification of 'blitz' therapy to eradicate Streptococcus agalactiae from a dairy herd. Vet Rec 125(24), 591-593.

Ellis KA, Innocent G, Grove-White D et al. (2006) Comparing the fatty acid composition of organic and conventional milk. J Dairy Sci 89(6), 1938-1950.

Ellis KA, Monteiro A, Innocent GT, et al. (2007) Investigation of the vitamins $A$ and $E$ and beta-carotene content in milk from UK organic and conventional dairy farms. J Dairy Res 74(4), 484-491.

Erskine RJ, Eberhart RJ (1990) Herd benefit-to-cost ratio and effects of a bovine mastitis control programme that includes blitz treatment of Streptococcus agalactiae. J Am Vet Med Assoc 196(8), 1230-1235.

FAO (2002) World agriculture 2030: Main findings [Online]. Available from: www.fao.org/english/newsroom/ news/2002/7833-en.html [Accessed December 7 2008].

FAO (2007) State of the World's Farm Animal Genetic Resources [Online]. Available from: www.fao.org/Ag/ AGAlnfo/programmemes/en/genetics/documents/ AH473e01.pdf [Accessed December 7 2008].

Field TR, Ward PN, Pedersen LH et al. (2003) The hyaluronic acid capsule of Streptococcus uberis is not required for the development of infection and clinical mastitis. Infect Immun 71(1), 132-139.

Fitzgerald JR, Hartigan PJ, Meaney WJ et al. (2000) Molecular population and virulence factor analysis of Staphylococcus aureus from bovine intramammary infection. J Appl Microbiol 88(6), 1028-1037.

Fitzgerald JR, Meaney WJ, Hartigan PJ et al. (1997) Fine-structure molecular epidemiological analysis of Staphylococcus aureus recovered from cows. Epidemiol Infect 119(2), 261-269.
Fox LK, Kirk JH and Britten A (2005) Mycoplasma mastitis: a review of transmission and control. J Vet Med $B$ Infect Dis Vet Public Health 52(4), 153-60.

Foxman B, D'Arcy H, Gillespie B et al. (2002) Lactation mastitis: occurrence and medical management among 946 breastfeeding women in the United States. Am J Epidemiol 155(2), 103-114.

Freeman AR, Meghen CM, Machugh DE et al. (2004) Admixture and diversity in West African cattle populations. Mol Ecol 13(11), 3477-3487.

Gianneechini R, Concha C, Rivero R et al. (2002) Occurrence of clinical and sub-clinical mastitis in dairy herds in the West Littoral Region in Uruguay. Acta Vet Scand 43(4), 221-230.

González RN, Wilson DJ (2003) Mycoplasmal mastitis in dairy herds. Vet Clin North Am Food Anim Pract 19(1), 199-221.

Graber HU, Casey MG, Naskova J et al. (2007) Development of a highly sensitive and specific assay to detect Staphylococcus aureus in bovine mastitic milk. J Dairy Sci 90(10), 4661-4669.

Green MJ, Leach KA, Breen JE et al. (2007) National intervention study of mastitis control in dairy herds in England and Wales. Vet Rec 160(9), 287-293.

Guinane CM, Sturdevant DE, Herron-Olson L et al. (2008) Pathogenomic analysis of the common bovine Staphylococcus aureus clone (ET3): emergence of a virulent subtype with potential risk to public health. J Infect Dis 197(2), 205-213.

Hamilton C, Emanuelson U, Forslund K, et al. (2006) Mastitis and related management factors in certified organic dairy herds in Sweden. Acta Vet Scand 17(48), 11, doi:10.1186/1751-0147-48-11.

Hansen SM, Uldbjerg N, Kilian M et al. (2004) Dynamics of Streptococcus agalactiae colonisation in women during and after pregnancy and in their infants. J Clin Microbiol 42(1), 83-89.

Heins BJ, Hansen LB and Seykora AJ (2006) Production of pure Holstein versus crossbreds of Holstein with Normande, Montbeliarde, and Scandinavian Red. J Dairy Sci 89(7), 2799-2804.

Heringstad B, Klemetsdal G and Steine T (2007) Selection responses for disease resistance in two selection experiments with Norwegian red cows. J Dairy Sci 90(5), 2419-2426.

Herron-Olson L, Fitzgerald JR, Musser JM et al. (2007). Molecular correlates of host specialisation in Staphylococcus aureus. PLoS ONE. 2(10), e1120.

Hill H, Lynchehaun F (2002) Case Study Organic milk: attitudes and consumption patterns. British Food J 104(7), 526-542.

Hillerton JE, Bramley AJ, Staker RT et al. (1995) Patterns of intramammary infection and clinical mastitis over a five year period in a closely monitored herd applying mastitis control measures. J Dairy Res 62(1), 39-50.

Hillerton JE, Leigh JA, Ward PN et al. (2004) Streptococcus agalactiae infection in dairy cows. Vet Rec 154(21), 671-672.

Hillerton JE, Shearn MF, Teverson RM et al. (1993) Effect of pre-milking teat dipping on clinical mastitis on dairy farms in England. J Dairy Res 60(1), 31-41.

Hoe FG, Ruegg PL (2005) Relationship between antimicrobial 
susceptibility of clinical mastitis pathogens and treatment outcome in cows. J Am Vet Med Assoc 227(9), 1461-1468.

Hortet P, Seegers H (1998) Calculated milk production losses associated with elevated somatic cell counts in dairy cows: review and critical discussion. Vet Res 29(6), 497-510.

Huijps K, Lam TJ and Hogeveen H (2008) Costs of mastitis: facts and perception. J Dairy Res 75(1), 113-120.

Jensen NE (1982) Experimental bovine group-B streptococcal mastitis induced by strains of human and bovine origin. Nord Vet Med 34(12), 441-450.

Joo YS, Fox LK, Davis WC et al. (2001) Staphylococcus aureus associated with mammary glands of cows: genotyping to distinguish different strains among herds. Vet Microbiol 80(2), 131-138.

Juhász-Kaszanyitzky E, Jánosi S, Somogyi P et al. (2007) MRSA transmission between cows and humans. Emerg Infect Dis 13(4), 630-632.

Kamiski S, Ciesliska A and Kostyra E (2007) Polymorphism of bovine beta-casein and its potential effect on human health. J Appl Genet 48(3), 189-198.

Kapur V, Sischo WM, Greer RS et al. (1995) Molecular population genetic analysis of Staphylococcus aureus recovered from cows. J Clin Microbiol 33(2), 376-380.

Karimuribo ED, Fitzpatrick JL, Bell CE et al. (2006) Clinical and subclinical mastitis in smallholder dairy farms in Tanzania: risk, intervention and knowledge transfer. Prev Vet Med 74(1), 84-98.

Kehrli ME, Harp JA (2001) Immunity in the mammary gland. Vet Clin North Am Food Anim Pract 17(3), 495-516.

Kelton DF (2006) Epidemiology: a foundation for dairy production medicine. Vet Clin North Am Food Anim Pract 22(1), 21-33.

Lam TJGM, Jansen J, Van den Borne B et al. (2007) A structural approach of udder health improvement via private practitioners: ups and downs. In: NMC 46th Annual Meeting Proceedings, San Antonio, Texas, USA. Pp 142-151.

Langford FM, Rutherford KM, Jack MC et al. (2008) A comparison of management practices, farmer-perceived disease incidence and winter housing on organic and non-organic dairy farms in the UK. J Dairy Res 76(1), 6-14.

LeBlanc SJ, Lissemore KD, Kelton DF et al. (2006) Major advances in disease prevention in dairy cattle. J Dairy Sci 89(4), 1267-1279.

Leigh JA (1999) Streptococcus uberis: a permanent barrier to the control of bovine mastitis? Vet J 157(3), 225-238.

Leigh JA, Field TR and Williams MR (1990) Two strains of Streptococcus uberis, of differing ability to cause clinical mastitis, differ in their ability to resist some host defence factors. Res Vet Sci 49(1), 85-87.

Leigh JA, Ward PN and Field TR (2004) The exploitation of the genome in the search for determinants of virulence in Streptococcus uberis. Vet Immunol Immunopathol 100(3-4), 145-149.

Licitra G, Blake RW, Oltenacu PA et al. (1998) Assessment of the dairy production needs of cattle owners in southeastern Sicily. J Dairy Sci 81(9), 2510-2517.

Lippolis JD, Reinhardt TA (2005) Proteomic survey of bovine neutrophils. Vet Immunol Immunopathol 103(1-2),
53-65.

Lopez-Benavides MG, Williamson JH, Pullinger GD et al. (2007) Field observations on the variation of Streptococcus uberis populations in a pasture-based dairy farm. J Dairy Sci 90(12), 5558-5566.

Lovett DK, Shalloo L, Dillon P et al. (2006) A systems approach to quantify greenhouse gas fluxes from pastoral dairy production as affected by management regime. Agr Systems 88(2-3), 156-179.

Manning S, Tallman P and Foxman B (2000) Prevalence and co-colonisation with group b streptococcus (GBS) among heterosexual college couples. Ann Epidemiol 10(7), 472.

Matthews KR, Almeida RA and Oliver SP (1994). Bovine mammary epithelial cell invasion by Streptococcus uberis. Infect Immun 62(12), 5641-5646.

McAllister AJ (2002) Is crossbreeding the answer to questions of dairy breed utilisation? J Dairy Sci 85(9), 2352-2357.

McDougall S (2003) Intramammary treatment of clinical mastitis of dairy cows with a combination of lincomycin and neomycin, or penicillin and dihydrostreptomycin. N Z Vet J 51(3), 111-116.

McDougall S, Parkinson TJ, Leyland M et al. (2004) Duration of infection and strain variation in Streptococcus uberis isolated from cows' milk. J Dairy Sci 87(7), 2062-2072.

Mehrzad J, Duchateau L and Burvenich C (2004) Viability of milk neutrophils and severity of bovine coliform mastitis. J Dairy Sci 87(12), 4150-4162.

Meyn LA, Moore DM, Hillier SL et al. (2002) Association of sexual activity with colonisation and vaginal acquisition of group B Streptococcus in nonpregnant women. Am J Epidemiol 155(10), 949-957.

Middleton JR, Fox LK (2002) Influence of Staphylococcus aureus strain on mammary quarter milk production. Vet Rec 150(13), 411-413.

Mikko S, Andersson L (1995) Low major histocompatibility complex class II diversity in European and North American moose. Proc Nat. Acad Sci U S A 92(10), 4259-4263.

Milne MH, Barrett DC, Fitzpatrick JL et al. (2002) Prevalence and aetiology of clinical mastitis on dairy farms in Devon. Vet Rec 151(8), 241-243.

Milne MH, Biggs AM, Barrett DC et al. (2005) Treatment of persistent intramammary infections with Streptococcus uberis in dairy cows. Vet Rec 157(9), 245-250.

Moon JS, Lee AR, Kang HM et al. (2007) Phenotypic and genetic antibiogram of methicillin-resistant staphylococci isolated from bovine mastitis in Korea. J Dairy Sci 90(3), 1176-1185.

Msanga YN, Bryant MJ, Rutam IB et al. (2000) Effect of environmental factors and of the proportion of Holstein blood on the milk yield and lactation length of crossbred dairy cattle on smallholder farms in north-east Tanzania. Trop Anim Health Prod 32(1), 23-31.

Mullarky IK, Su C, Frieze N et al. (2001) Staphylococcus aureus agr genotypes with enterotoxin production capabilities can resist neutrophil bactericidal activity. Infect Immun 69(1), 45-51.

Müller A, Schmidhuber J, Hoogeveen J et al. (2008) Some insights in the effect of growing bioenergy demand on global food security and natural resources. Water Policy 10(S1), 83-94. 
Mulligan FJ, O'Grady L, Rice DA et al. (2006) A herd health approach to dairy cow nutrition and production diseases of the transition cow. Anim Reprod Sci 96(3-4), 331353.

Munoz MA, Ahlström C, Rauch BJ et al. (2006) Fecal shedding of Klebsiella pneumoniae by dairy cows. J Dairy Sci 89(9), 3425-3430.

Munoz MA, Welcome FL, Schukken YH et al. (2007) Molecular epidemiology of two Klebsiella pneumoniae mastitis outbreaks on a dairy farm in New York State. J Clin Microbiol 45(12), 3964-3971.

Myllys V, Asplund K, Brofeldt E et al. (1998) Bovine mastitis in Finland in 1988 and 1995: changes in prevalence and antimicrobial resistance. Acta Vet Scand 39(1), 119126.

Neave FK, Dodd FH, Kingwill RG et al. (1969) Control of mastitis in the dairy herd by hygiene and management. J Dairy Sci 52(5), 696-707.

Nielsen HM, Christensen LG and Odegård J (2006) A method to define breeding goals for sustainable dairy cattle production. J Dairy Sci 89(9), 3615-3625.

Nightingale C, Dhuyvetter K, Mitchell R et al. (2008) Influence of variable milk quality premiums on observed milk quality. J Dairy Sci 91(3), 1236-1244.

NMC (2008). [Online] Available from: www.nmconline.org/ translations.html [Accessed December 7 2008].

Oltenacu PA, Algers B (2005) Selection for increased production and the welfare of dairy cows: are new breeding goals needed? Ambio 34(4-5), 311-315.

Opsal MA, Lien S, Brenna-Hansen S et al. (2008) Association analysis of the constructed linkage maps covering TLR2 and TLR4 with clinical mastitis in Norwegian Red cattle. J Anim Breed Genet 125(2): 110118.

Østerås O, Sølverød L and Reksen 0 (2006) Milk culture results in a large Norwegian survey-effects of season, parity, days in milk, resistance, and clustering. J Dairy Sci 89(3), 1010-1023.

Park YH, Fox LK, Hamilton MJ et al. (1993) Suppression of proliferative response of BoCD4+ T lymphocytes by activated BoCD8+ T lymphocytes in the mammary gland of cows with Staphylococcus aureus mastitis. Vet Immunol Immunopathol 36(2), 137-151.

Patz JA, Campbell-Lendrum D, Holloway T et al. (2005) Impact of regional climate change on human health. Nature 438(7066), 310-317.

Paulin-Curlee GG, Singer RS, Sreevatsan S et al. (2007) Genetic diversity of mastitis-associated Klebsiella pneumoniae in dairy cows. J Dairy Sci 90(8), 36813689.

Peeler EJ, Green MJ, Fitzpatrick JL et al. (2003) The association between quarter somatic-cell counts and clinical mastitis in three British dairy herds. Prev Vet Med 59(3), 169-180.

Piepers S, de Meulemeester L, de Kruijff A et al. (2007) Prevalence and distribution of mastitis pathogens in subclinically infected dairy cows in Flanders, Belgium. J Dairy Res 74(4), 478-483.

Pullinger GD, Lopez-Benavides M, Coffey TJ et al. (2006) Application of Streptococcus uberis multilocus sequence typing: analysis of the population structure detected among environmental and bovine isolates from New
Zealand and the United Kingdom. Appl Environ Microbiol 72(2), 1429-1436.

Quality Milk Production Services (2008). [Online] Available from: http://qmps.vet.cornell.edu/education/ milkertraining.htm [Accessed December 7 2008].

Rainard P, Riollet C (2006) Innate immunity of the bovine mammary gland. Vet Res 37(3), 369-400.

Rajala-Schultz PJ, Smith KL, Hogan JS et al. (2004) Antimicrobial susceptibility of mastitis pathogens from first lactation and older cows. Vet Microbiol 102(1-2), 33-42.

Rendo F, Iriondo M, Jugo BM et al. (2004) Analysis of the genetic structure of endangered bovine breeds from the Western Pyrenees using DNA microsatellite markers. Biochem Genet 42(3-4), 99-108.

Rivas AL, González RN, Wiedmann M et al. (1997) Diversity of Streptococcus agalactiae and Staphylococcus aureus ribotypes recovered from New York dairy herds. Am J Vet Res 58(5), 482-487.

Roesch M, Doherr MG and Blum JW (2006) Management, feeding, production, reproduction and udder health on organic and conventional Swiss dairy farms. Schweiz Arch Tierheilkd 148(8), 387-395.

Rotz CA, Kamphuis GH, Karsten HD et al. (2007) Organic dairy production systems in Pennsylvania: a case study evaluation. J Dairy Sci 90(8), 3961-3979.

Ruegg P (2008) Management of mastitis on organic \& conventional dairy farms. J Anim Sci Sep 26. [Epub ahead of print], 0: jas.2008-1217v1-jas.2008-1217

Sampimon OC, Sol J and Kock PA (2006). Een uitbraak van Klebsiella pneumoniae mastitis. Tijdschr Diergeneeskd 131(1), 2-4. (English summary: An outbreak of Klebsiella pneumoniae mastitis).

Sampimon OC, Vernooij JC, Mevius DJ et al. (2007) Gevoeligheid voor diverse antibiotica van coagulase negatieve staphylococcen, geïsoleerd uit melkmonsters van Nederlands rundvee. Tijdschr Diergeneeskd 132(6), 200-204. (English summary: Sensitivity to various antibiotics of coagulase-negative staphylococci isolated from samples of milk from Dutch dairy cattle).

Sharif S, Mallard BA and Wilkie BN (2003) Characterisation of naturally processed and presented peptides associated with bovine major histocompatibility complex (BoLA) class II DR molecules. Anim Genet 34(2), 116123.

Shkreta L, Talbot BG, Diarra MS et al. (2004) Immune response to a DNA/protein vaccination strategy against Staphylococcus aureus induced mastitis in dairy cows. Vaccine 23(1), 114-126.

Shook GE (2006). Major advances in determining appropriate selection goals. J Dairy Sci 89(4), 1349-1361.

Smith EM, Green LE, Medley GF et al. (2005) Multilocus sequence typing of intercontinental bovine Staphylococcus aureus isolates. J Clin Microbiol 43(9), 4737-4743.

Smith TH, Fox LK and Middleton JR (1998) Outbreak of mastitis caused by one strain of Staphylococcus aureus in a closed dairy herd. J Am Vet Med Assoc 212(4), 553-556.

Smolenski G, Haines S, Kwan FY et al. (2007) Characterisation of host defence proteins in milk using a proteomic approach. J Proteome Res 6(1), 207-15. 
Sukhnanand S, Dogan B, Ayodele MO et al. (2005) Molecular subtyping and characterisation of bovine and human Streptococcus agalactiae isolates. J Clin Microbiol 43(3), 1177-1186.

Suriyasathaporn W, Heuer C, Noordhuizen-Stassen EN et al. (2000a) Hyperketonemia and the impairment of udder defense: a review. Vet Res 31(4), 397-412.

Suriyasathaporn W, Schukken YH, Nielen M et al. (2000b) Low somatic cell count: a risk factor for subsequent clinical mastitis in a dairy herd. J Dairy Sci 83(6), 12481255.

Tamilselvam B, Almeida RA, Dunlap JR et al. (2006) Streptococcus uberis internalises and persists in bovine mammary epithelial cells. Microb Pathog 40(6), 279285.

Taverna F, Negri A, Piccinini R et al. (2007) Characterization of cell wall associated proteins of a Staphylococcus aureus isolated from bovine mastitis case by a proteomic approach. Vet Microbiol 119(2-4), 240-247.

Tenhagen BA, Koster G, Wallmann J et al. (2006) Prevalence of mastitis pathogens and their resistance against antimicrobial agents in dairy cows in Brandenburg, Germany. J Dairy Sci 89(7), 2542-2551.

Tolboom RK, Snoep JJ, Sampimon OC et al. (2008) Mycoplasma mastitis bij het rund. Tijdschr Diergeneeskd 133(3), 96-101. (English summary: Mycoplasma mastitis in dairy cattle).

Tomita T, Meehan B, Wongkattiya N et al. (2008) Identification of Streptococcus uberis multilocus sequence types highly associated with mastitis. Appl Environ Microbiol 74(1), 114-124.

Tomkins A (2000) Malnutrition, morbidity and mortality in children and their mothers. Proc Nutr Soc 59(1), 135146.

UN (2004). World population prospects: The 2004 revision. [Online]. Available from: www.un.org/esa/population/ publications/WPP2004/WPP2004_Volume3.htm [Accessed December 7 2008\}.

University of Wisconsin (2008). [Online] Available from: www. uwex.edu/milkquality/Spanish_Resources/index.htm [Accessed December 7 2008]

Vage DI, Lingaas F, Spooner RL et al. (1992) A study on association between mastitis and serologically defined class I bovine lymphocyte antigens (BoLA-A) in Norwegian cows. Anim Genet 23(6), 533-536.

Van Loo I, Huijsdens X, Tiemersma E et al. (2007) Emergence of methicillin-resistant Staphylococcus aureus of animal origin in humans. Emerg Infect Dis 13(12), 1834-1839.

VanRaden PM (2004) Invited review: selection on net merit to improve lifetime profit. J Dairy Sci 87(10), 31253131.

Vecht U, Meijers KC and Wisselink HJ (1987) Klebsiella pneumoniae mastitis als bedrijfsprobleem. Tijdschr Diergeneeskd 112(11), 653-659. (English summary: Klebsiella pneumoniae mastitis as a dairying problem).

Vicini J, Etherton T, Kris-Etherton P et al. (2008) Survey of retail milk composition as affected by label claims regarding farm-management practices. J Am Dietetic Assoc 108(7), 1198-1203

Weigel KA, Freeman AE, Kehrli ME et al. (1990) Assocation of class I bovine lymphocyte antigen complex alleles with health and production traits in dairy cattle. J Dairy Sci 73(9), 2538-2546.

Wein LM, Liu Y (2005) Analyzing a bioterror attack on the food supply: the case of botulinum toxin in milk. Proc Natl Acad Sci U S A 102(28), 9984-9989.

Whist AC, Østerås 0 and Sølverød L (2007) Streptococcus dysgalactiae isolates at calving and lactation performance within the same lactation. J Dairy Sci 90(2), 766-778.

Wicks HC, Leaver JD (2006) Influence of genetic merit and environment on somatic cell counts of Holstein-Friesian cows. Vet J 172(1), 52-57.

Wieliczko RJ, Williamson JH, Cursons RT et al. (2002) Molecular typing of Streptococcus uberis strains isolated from cases of bovine mastitis. J Dairy Sci 85(9), 21492154.

Wilson DJ, González RN and Das HH (1997) Bovine mastitis pathogens in New York and Pennsylvania: prevalence and effects on somatic cell count and milk production. J Dairy Sci 80(10), 2592-2598.

Yamagata M, Goodger WJ, Weaver L et al. (1987) The economic benefit of treating subclinical Streptococcus agalactiae mastitis in lactating cows. J Am Vet Med Assoc 191(12), 1556-1561.

Yildirim AO, Lämmler C, Weiss R et al. (2002) Pheno- and genotypic properties of streptococci of serological group B of canine and feline origin. FEMS Microbiol Lett 212(2), 187-192.

Zadoks R, van Leeuwen W, Barkema H et al. (2000) Application of pulsed-field gel electrophoresis and binary typing as tools in veterinary clinical microbiology and molecular epidemiologic analysis of bovine and human Staphylococcus aureus isolates. J Clin Microbiol 38(5), 1931-1939.

Zadoks RN (2007) Sources and epidemiology of Streptococcus uberis, with special emphasis on mastitis in dairy cattle. CAB Reviews: Perspectives in Agriculture, Veterinary Science, Nutrition and Natural Resources 2(030), $15 \mathrm{pp}$

Zadoks RN, Schukken YH (2006) Use of molecular epidemiology in veterinary practice. Vet Clin North Am Food Anim Pract 22(1), 229-261.

Zadoks RN, Watts JL (2008) Species identification of coagulase-negative staphylococci: Genotyping is superior to phenotyping. Vet Microbiol. 134(1-2), 20-28

Zadoks RN, Gillespie BE, Barkema HW et al. (2003) Clinical, epidemiological and molecular characteristics of Streptococcus uberis infections in dairy herds. Epidemiol Infect 130(2), 335-349.

Zadoks RN, van Leeuwen WB, Kreft D et al. (2002) Comparison of Staphylococcus aureus isolates from bovine and human skin, milking equipment, and bovine milk by phage typing, pulsed-field gel electrophoresis, and binary typing. J Clin Microbiol 40(11), 3894-3902. 